\section{Personality traits and intrapreneurial behaviour} \section{Moderated role of knowledge sharing behaviour} in diverse group of employees in developing country

\author{
Muhammad Zubair Alam \\ Department of Management Science, Superior University, Lahore, Pakistan \\ Shazia Kousar \\ Superior University, Lahore, Pakistan \\ Aiza Shabbir \\ Department of Management Science, Superior University, Lahore, Pakistan, and \\ Muhammad Ali Kaleem \\ National University of Sciences and Technology, Islamabad, Pakistan
}

\section{Role of knowledge sharing behaviour}

\begin{abstract}
Purpose - Intrapreneurship is rapidly concerning organizations to tailor their operations and strategies for competitive advantage. Research on intrapreneurial dimensions is in the developing stage, requiring more rigorous methods of investigation and application in various contexts. This study aims to focus on individual level intrapreneurship by examining the association of personality traits (PTs) on intrapreneurial behaviour (IB) moderated by knowledge sharing behaviour (KSB) and comparison of employees in engineering and functional departments.
\end{abstract}

Design/methodology/approach - A survey has been conducted for data collection using a structured questionnaire. Partial least squares structural equation modelling has been used for hypotheses testing, moderation and multi-group analysis on a sample of 534 respondents.

Findings - Results reveal that PTs exerted a positive influence on IB. The impact of PTs on IB was more pronounced in the employees of functional departments. KSB moderates positively in the relationship between PTs and IB. Both groups significantly differ in dimensions of PTs.

Practical implications - Organizations can do little to improve PTs of employees, which impacts on intrapreneurship in organizations. However, KSB in organizations can be improved by adopting various measures. KSB eventually promotes innovation in organizations resulting in an overall competitive advantage for firms.

Originality/value - This is the first study that contributes theoretically in intrapreneurship literature by providing insights on PTs impacting IB incorporating KSB and comparing the diverse group of employees.

Keywords Intrapreneurial behaviour, Personality traits, Knowledge sharing behaviour, Structural equation modelling, Psychology

Paper type Research paper

(C) Muhammad Zubair Alam, Shazia Kousar, Aiza Shabbir and Muhammad Ali Kaleem. Published in Asia Pacific Journal of Innovation and Entrepreneurship. Published by Emerald Publishing Limited. This article is published under the Creative Commons Attribution (CC BY 4.0) licence. Anyone may reproduce, distribute, translate and create derivative works of this article (for both commercial and non-commercial purposes), subject to full attribution to the original publication and authors. The full terms of this licence may be seen at http://creativecommons.org/licences/by/4.0/legalcode

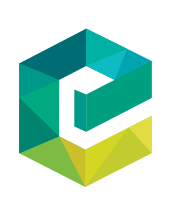

Asia Pacific Journal of Innovation and Entrepreneurship Vol. 14 No. 1, 2020 pp. $31-46$ Emerald Publishing Limited e-ISSN: 2398-7812 p-ISSN: 2071-1395 DOI 10.1108/APJE-09-2019-0068 
APJIE

14,1

\section{Introduction}

Innovation and intrapreneurship are increasingly becoming a competitive strategy in existing organizations and is considered a promising area, requiring further exploration, by academic researchers (Ağca et al., 2012). Various perspectives (individual and organization) related to entrepreneurship within firms with fragmented theoretical basis have been evolved. The definition of intrapreneurship, due to the rapidly emerging field, is inconsistent (Menzel et al., 2007; Åmo and Kolvereid, 2005) resulting in various theoretical perspectives. The phenomenon, due to diverse theoretical foundations, resulted in concepts such as corporate entrepreneurship (Ireland et al., 2009), entrepreneurial orientation (Covin and Wales, 2012) and corporate venturing (Antoncic and Hisrich, 2003), building further confusion in intrapreneurship research (Valsania et al., 2016).

Studies on intrapreneurship have been conducted for investigating antecedents, outcomes and conditions of intrapreneurship (Farrukh et al., 2017; Ireland et al., 2009; Antoncic and Hisrich, 2003), effects of employee's innovation on firm performance (Sieger et al., 2013; Augusto Felício et al., 2012; Shin and Lee, 2016) and leadership role on intrapreneurship (Mittal and Dhar, 2015). Recently, with an increase in interest in intrapreneurship, researchers have focussed on investigating personality traits (PTs) as an antecedent of intrapreneurship (Woo, 2018).

The hypotheses model in this study has been developed by including Knowledge sharing behaviour (KSB) as a moderator between PTs of employees and intrapreneurship. Knowledge sharing is a process of transferring knowledge from one aspect to some other aspect (Matzler et al., 2008). Knowledge sharing can function between individuals, teams and organizations. In this study, KSB is considered to enhance the effects of PTs on intrapreneurship as existing literature stresses employee creativity as an outcome of knowledge sharing (Imran et al., 2018). Knowledge sharing also contributes to firm performance (Argote and Ingram, 2000). This study contributes theoretically to intrapreneurship literature by providing insights on PTs impacting IB and comparing the difference between diverse groups of employees. This study also presents implications for firms seeking intrapreneurship as a competitive advantage in discovering the benefits of knowledge sharing in the development of intrapreneurship and innovation within firms.

\section{Literature review and hypotheses formation \\ Intrapreneurship}

Intrapreneurship is used to describe entrepreneurial development and innovation efforts of employees at existing organizations (Burgers and Covin, 2016). Entrepreneurship as a notion has expanded from business start-up by entrepreneurs (Park, 2017) to value creation in existing organizations through entrepreneurial efforts by employees (Antoncic and Hisrich, 2003). Intrapreneurship is considered a much broader field that has expended towards innovation efforts of employees (Sinha and Srivastava, 2013), the joint venture (Espinosa and Suanes, 2011) and venture teams (Dushnitsky and Lavie, 2010). Firm performance-related studies as an outcome of intrapreneurship have attracted researchers in the past. In intrapreneurial domain, innovation (Wang et al., 2015), knowledge creation (Zahra, 2015), sustainability (Halme et al., 2012) and effects on the firm's performance (Tseng and Tseng, 2019) have been studied. Corporate entrepreneurship and intrapreneurship has expanded from large organizations to small- and medium-sized enterprises and further towards not for profit or public organizations (Srivastava et al., 2017). Still, this research area requires rigorous research by incorporating mediators and moderators in theoretical frameworks of intrapreneurship to strengthen the concept (Kuratko, 2017). 
Personality as a concept has been described as attitudes, stable motives and direction of actions and experiences of people (Meyer et al., 2014). Personality is also considered to form the behaviour of individuals in any society (Lim and Melissa Ng Abdullah, 2012). On the basis of career choice theory and various other theoretical perspectives like person environment-fit theory, personality should be the basis of an individual's career choice (Zhao et al., 2010).

So far, intrapreneurship is an auxiliary of entrepreneurship and fewer studies have been conducted on PTs and intrapreneurship, hence, personality and entrepreneurship relations could be considered for intrapreneurship based studies (Kirkley, 2017). In entrepreneurship research "Big Five" or "Five Factor Model" is widely used (Fietze and Boyd, 2017) and dominated the previous research on individual-level PTs studies (John et al., 2008). "Big Five" PTs consist of openness, conscientiousness, extraversion, neuroticism (antonym emotional stability) and agreeableness (Goldberg, 1992).

Previous researchers have established that a high level of extraversion, conscientiousness and openness have a positive relationship with entrepreneurship (Obschonka and Stuetzer, 2017). In a meta-analysis by Zhao et al. (2010), openness and conscientiousness were found to have a strong relationship with entrepreneurial performance and intention. While, the other two PTs of "Big Five" neuroticism and agreeableness are found by researchers as negatively linked with intrapreneurship (Obschonka and Stuetzer, 2017). In lines with previous findings of researchers, this study intends to investigate the relationship of openness, extraversion and conscientiousness with IB.

Extraversion is linked with dominance, ambition and energy (Costa and McCrae, 1992), which stimulate motivation in individuals (Costa and McCrae, 1992). Extravert people seek stimulation, excitement and remain optimistic and positive (Burtăverde et al., 2017). Low extraversion leads individuals towards isolation, passiveness and loneliness. Innovation is the outcome of an individual's stimulation and ambition. Thus, extravert people are more engaged in intrapreneurial and innovative efforts than those in traditional jobs (Farrukh et al., 2016; Sinha and Srivastava, 2013). In lines with previous research, hypothesis for direct relationship is as under:

\section{H1. Extraversion is positively associated with IB.}

People who characterized to have high on openness are more creative, non-traditional and curious (Costa and McCrae, 1992). Those who found to be low on openness are more conservative towards norms and traditions as it reduces uncertainty and risk-taking (Choi, 2004). Openness is associated with innovation (Steel et al., 2012) and risk-taking, which are described as vital elements of intrapreneurship (Sinha and Srivastava, 2013). Our hypothesis for the direct relationship of openness with intrapreneurship is as under:

H2. Openness is positively associated with IB.

Conscientiousness is characterized by the qualities of self-control, planning behaviour, work achievement and goal orientation (Burtăverde et al., 2017). As regards the relationship of conscientiousness and innovation or intrapreneurship, two parallel streams of literature are existent, which makes relationships vague to hypothesise. Few traits of conscientiousness such as goal-oriented behaviour, hard work and self-discipline are requirements of innovativeness (Barrick and Mount, 1991). Researchers believe that people high on conscientiousness are more compliant with existing norms and resist changes, which somewhat opposes innovativeness (George and Zhou, 2001). While, innovative people 
always challenge the existing norms and find out of box solutions (Bakx, 2007). Conscientious people are found to have clear goals and they put more effort towards their task as compared to less conscientious people (Barrick and Mount, 1991). According to Zhao et al. (2010), conscientiousness is an important component of motivation. Conscientious people are more motivated and goal-oriented, which attracted intrapreneurial careers over traditional jobs (Farrukh et al., 2016; Sinha and Srivastava, 2013). Hence, in lines with Farrukh et al. (2016) and Sinha and Srivastava (2013), the hypothesis of a direct relationship between conscientiousness and IB is as under:

H3. Conscientiousness is positively associated with IB.

\section{Moderated role of knowledge sharing behaviour in personality traits and intrapreneurial behaviour}

Knowledge formation stimulates creativity (Wang, 2010), which is essential for organizations. Researchers have studied the association of individual PTs and knowledge sharing in the context of firm performance. Conscientiousness and performance relationship has been studied by Barrick et al. (2001) and argued that low conscientiousness is hard to associate in terms of better job performance due to careless, impulsive and low thirst for success. Employees high in conscientiousness develop organizational citizenship, which are contributions of employees beyond their assigned tasks and mandated role (Organ and Ryan, 1995). As knowledge sharing is part of organizational citizenship, hence, it is an important constituent of conscientiousness.

People who score high on openness are found to be more creative, flexible in thinking, curious (Digman, 1990) and have a positive attitude towards engaging, learning new ideas and things (Barrick and Mount, 1991). Openness has found to be a strong predictor of knowledge sharing as curiosity leads to seeking other people's perceptions and experiences (Cabrera et al., 2006). Hence, people with high openness are more willing towards mutual knowledge sharing and transferring.

Extraversion is linked with ambition and energy (Hurtz and Donovan, 2000), which stimulates more engagement towards innovation and entrepreneurial activities (Farrukh et al., 2016). As innovativeness is linked with knowledge sharing (Wang, 2010), hence extraversion is a function of knowledge sharing.

Previous research has investigated the relationship of PTs with knowledge sharing (Matzler et al., 2008). Little or no research has so far examined the moderating role of knowledge sharing between PTs and IB specifically within employees of diverse firms. It is important for firms to retain a competitive advantage in the industry by raising its human resources through the acquisition of benefits of KSB of employees. To fill this gap in the literature, hypotheses for investigating the role of KSB between individual PTs and IB are as under:

H4, H5 and H6. KSB strengthens the positive relationship between PTs (extraversion, openness, conscientiousness) and IB.

Williamson et al. (2013) have carried out a study to compare PTs between engineers and non-engineers. Engineers have been found quite different in most of the PTs. The results of Williamson et al. (2013) studies mentioned that most of the PTs are less favourable for engineers as compared to non-engineers. Employees of different firms or departments are not the same in exhibiting PTs due to obvious effects on employees due to the nature of the 
job. Hence, it is important to consider the diversity of the job while studying PTs as a function of IB. Research hypothesis for difference in both group of employees is as under:

H7. The impact of PTs (extraversion, openness, and conscientiousness) on IB is likely to be different in employees of both groups (engineering, functional).
Role of knowledge sharing behaviour

The research model of the study is presented in Figure 1.

Methods

Sampling

Data collection has been done from employees of two types of departments (engineering and functional) from 12 organizations operating in different geographical regions of Pakistan. A total of 534 responses from employees have been included in the study. The sample includes 358 (67 per cent) male and 176 (33 per cent), female employees. In total, 274 (51.3 per cent) employees are included from engineering, whereas 260 (48.7 per cent) employees are included from functional departments.

\section{Instrumentation}

Latent constructs in this study including PTs, KSB and IB are well-established and valid scales are available in the literature. Scale for the measurement of "Big Five" PTs has been adapted from John and Srivastava (1999) studies. Reverse coding of a few of the items was done as per the requirement of scale. This scale is widely used by researchers in various studies in the past (Farrukh et al., 2016). Items of knowledge sharing have been adopted from Davenport and Prusak (1998) and behaviour from Kim and Lee (2004) studies. This scale has also been used and validated in previous studies (Gillani et al., 2018). Items of innovativeness (first-order construct of IB) have been adopted from Scott and Bruce (1994). Items of proactiveness (first-order construct of IB) are adopted from Parker and Collins (2010). Items of risk-taking (first-order construct of IB) have been adopted from Zhao et al. (2005). A five-point Likert scale has been used to measure items of constructs (strongly disagree - strongly agree).

\section{Data analysis}

As constructs used in the model are latent constructs with multiple items of measurement, hence, multivariate technique SEM is most appropriate for this study. SEM is a widely used approach in management science and entrepreneurship based studies (Alam et al., 2019). In this study, PLS-SEM is used as it is considered suitable for complex models containing

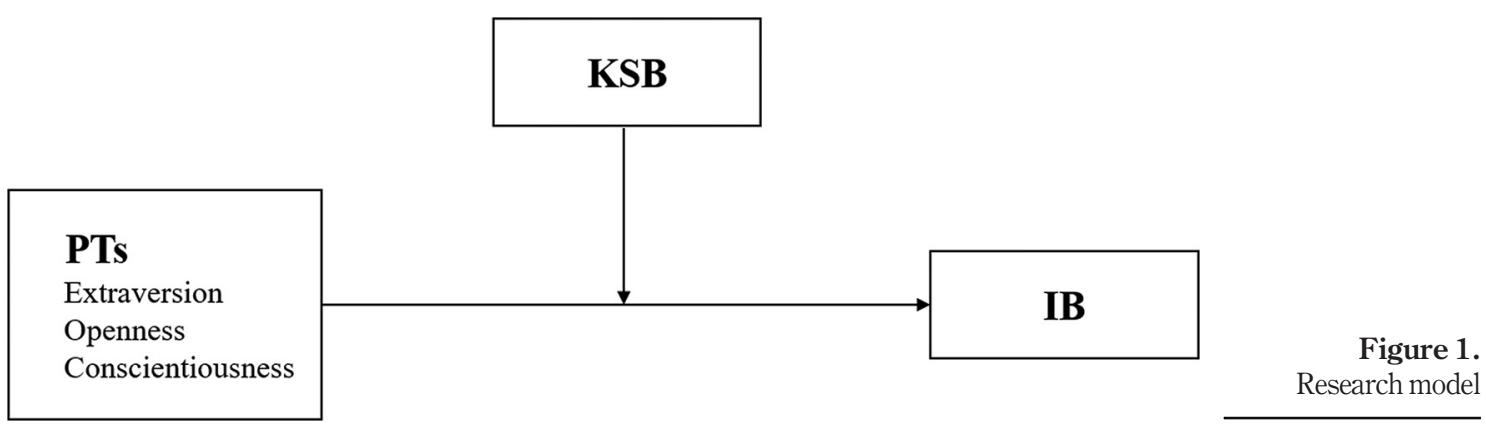


APJIE 14,1

latent variables and the sole purpose is the investigation of relationships at the theoretical level (Hair et al., 2019). PLS-SEM has been used through Smart PLS 3.2.6 software package (Hair et al., 2016), due to normality of data issues, friendly interface, nature of the study, level of measurement and small sample size requirements (Chin and Newsted, 1999).

\section{Results}

\section{$36 \quad$ Measurement model}

The reliability of all reflective measures was computed by using Cronbach's $\alpha$ value and composite reliability (CR). Convergent validity has been computed by using the average variance explained (AVE). Few items from scales of constructs have been excluded due to low factor loading. Remaining reflective item loadings are above the 0.7 threshold value, hence, meeting the necessary criteria (Hair et al., 2016). Table I presents the results of measurement model assessment (factor loadings, $\alpha, \mathrm{CR}$ and AVE). Discriminant validity of constructs has been established through the Fornell-Larcker criteria in which AVE values are examined to be higher than correlation among the constructs (Fornell and Larcker, 1981). Table II presents the result of discriminant validity. Hence, the measurement model is appropriate for further analysis. Variance inflation factors (VIFs) were found to be less than 5, hence, multi-collinearity issues in data were not there (Hair et al., 2011).

\begin{tabular}{|c|c|c|c|c|c|c|c|c|c|}
\hline \multirow{2}{*}{\multicolumn{2}{|c|}{$\begin{array}{c}\text { Construct/associated } \\
\text { items }\end{array}$}} & \multirow{2}{*}{$\begin{array}{l}\text { Engineering } \\
\quad \text { Factor l }\end{array}$} & \multirow{2}{*}{$\begin{array}{l}\text { Functional } \\
\text { ading }\end{array}$} & \multicolumn{3}{|c|}{ Engineering } & \multicolumn{3}{|c|}{ Functional } \\
\hline & & & & $\alpha$ & $\mathrm{CR}$ & AVE & $\alpha$ & $\mathrm{CR}$ & AVE \\
\hline \multirow[t]{6}{*}{ Conscientiousness } & Con_1 & 0.714 & 0.79 & 0.906 & 0.895 & 0.588 & 0.904 & 0.903 & 0.609 \\
\hline & Con_2 & 0.708 & 0.753 & & & & & & \\
\hline & Con_3 & 0.758 & 0.764 & & & & & & \\
\hline & Con_4 & 0.812 & 0.851 & & & & & & \\
\hline & Con_5 & 0.854 & 0.775 & & & & & & \\
\hline & Con_6 & 0.744 & 0.745 & & & & & & \\
\hline \multirow[t]{3}{*}{ Extraversion } & Ext_1 & 0.847 & 0.753 & 0.953 & 0.866 & 0.57 & 0.937 & 0.618 & 0.574 \\
\hline & Ext_2 & 0.863 & 0.852 & & & & & & \\
\hline & Ext_3 & 0.535 & 0.757 & & & & & & \\
\hline \multirow[t]{4}{*}{ Openness } & Ope_1 & 0.635 & 0.732 & 0.903 & 0.917 & 0.614 & 0.902 & 0.777 & 0.589 \\
\hline & Ope_2 & 0.836 & 0.842 & & & & & & \\
\hline & Ope_3 & 0.806 & 0.816 & & & & & & \\
\hline & Ope_4 & 0.792 & 0.812 & & & & & & \\
\hline \multirow{7}{*}{ KSB } & KSB_1 & 0.855 & 0.868 & 0.823 & 0.911 & 0.596 & 0.85 & 0.932 & 0.663 \\
\hline & KSB_2 & 0.788 & 0.802 & & & & & & \\
\hline & KSB_3 & 0.74 & 0.795 & & & & & & \\
\hline & KSB_4 & 0.796 & 0.791 & & & & & & \\
\hline & KSB_5 & 0.761 & 0.81 & & & & & & \\
\hline & KSB_6 & 0.712 & 0.779 & & & & & & \\
\hline & KSB_7 & 0.744 & 0.851 & & & & & & \\
\hline \multirow[t]{3}{*}{ Proactiveness } & Pro_1 & 0.764 & 0.827 & 0.786 & 0.864 & 0.681 & 0.789 & 0.901 & 0.753 \\
\hline & Pro_2 & 0.886 & 0.888 & & & & & & \\
\hline & Pro_3 & 0.821 & 0.886 & & & & & & \\
\hline \multirow{2}{*}{ Risk taking } & RT_1 & 0.906 & 0.952 & 0.794 & 0.869 & 0.692 & 0.752 & 0.869 & 0.7 \\
\hline & RT_2 & 0.736 & 0.816 & & & & & & \\
\hline \multirow{3}{*}{ Innovativeness } & Inn_1 & 0.841 & 0.894 & 0.867 & 0.935 & 0.827 & 0.872 & 0.945 & 0.852 \\
\hline & Inn_2 & 0.935 & 0.94 & & & & & & \\
\hline & Inn_3 & 0.854 & 0.87 & & & & & & \\
\hline
\end{tabular}

Table I.

Assessment of measurement model

$$
\text { than } 5 \text {, hence, muticollinearity issues in data were not there (Hair et al, 2011). }
$$




\section{Structural model}

With the confirmation of the measurement model, the structural model has been assessed using partial least square and structural equation modelling (PLS-SEM) for hypotheses testing. Bootstrapping technique with 2,000 sub-samples and $t$-statistics has been applied to explain relationships. Relationships of the structural models are assessed by path coefficient among the constructs (Hair et al., 2016). Bootstrapping function calculated $t$ statistics re-sampling (Hair et al., 2016), which are presented in Table III.

H4-H6 anticipated that KSB strengthens (moderates) the relationship between three hypothesised PTs. As the direct relationship of extraversion with IB is not established (H1 not accepted), hence, the need to check the moderating effect is not there (H4 not accepted). To test the moderating effect of KSB between the remaining two of the PTs (openness and conscientiousness), moderation analysis has been performed. KSB significantly moderates and strengthens the relationship between openness $(\beta=0.2826, p<0.05)$ and conscientiousness $(\beta=0.219, p<0.05)$ supporting hypotheses $H 5$ and $H 6$. Figure 2 showed the nature of the moderating effect obtained through plotting values of unstandardized $\beta$ of moderating effect, independent and dependent variables. The plot shows, with low KSB, openness and conscientiousness have less impact on IB. When KSB is high among

\begin{tabular}{|c|c|c|c|c|c|c|c|c|}
\hline Construct & 1 & 2 & 3 & 4 & 5 & 6 & 7 & \\
\hline Conscientiousness & 0.775 & & & & & & & \\
\hline Extraversion & 0.615 & 0.665 & & & & & & \\
\hline Innovativeness & 0.422 & 0.279 & 0.916 & & & & & \\
\hline KSB & 0.449 & 0.284 & 0.719 & 0.776 & & & & Table II. \\
\hline Openness & 0.526 & 0.523 & 0.404 & 0.44 & 0.699 & & & Discriminant validity \\
\hline Proactiveness & 0.405 & 0.286 & 0.652 & 0.709 & 0.408 & 0.846 & & (Fornell and \\
\hline Risk taking & 0.406 & 0.196 & 0.666 & 0.668 & 0.44 & 0.656 & 0.833 & Larker's criteria) \\
\hline
\end{tabular}

\begin{tabular}{lccccc}
\hline \multicolumn{1}{c}{ Hypotheses } & & $\beta$ & t-statistics & Decision \\
\hline Extraversion $\rightarrow$ IB & $H 1$ & -0.041 & 0.725 & Not accepted & Accepted Direct hypotheses \\
Openness $\rightarrow$ IB & $H 2$ & 0.14 & 2.204 & Accepted \\
Conscientiousness $\rightarrow$ IB & $H 3$ & 0.151 & 2.169 & testing \\
\hline
\end{tabular}

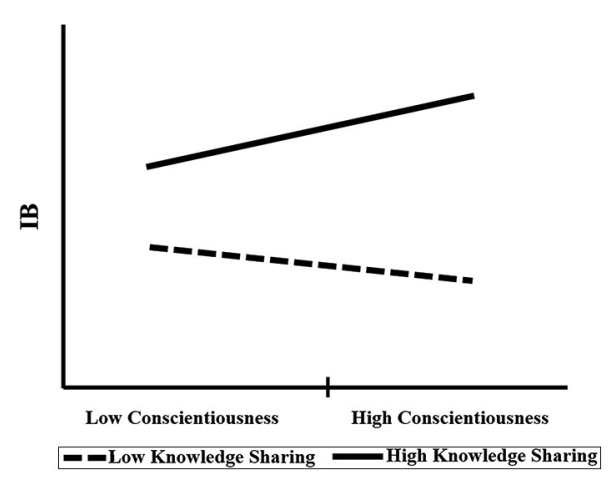

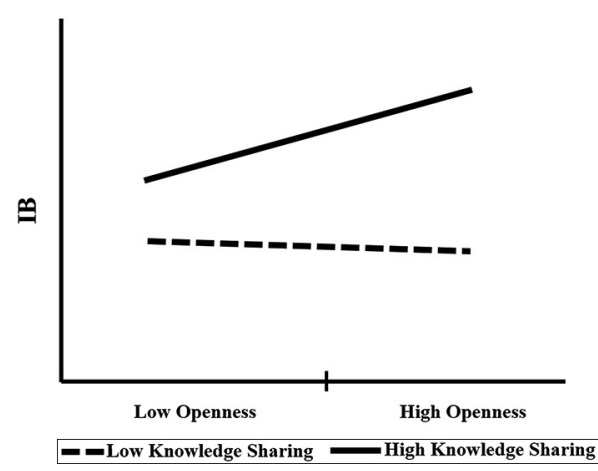

Figure 2. Moderating effect of KSB on PTs and IB 
APJIE 14,1

\section{8}

employees, the relationship between openness, conscientiousness and IB is strengthened. Hence, KSB strengthens the positive effect of openness and conscientiousness on IB.

Multi-group analysis (MGA) has been performed to examine the statistical differences between employees of engineering and functional departments. $H 7$ concerned the relationship of PTs and IB, which could vary across two samples. This study used PLS-MGA, which is a non-parametric approach using Henseler et al. (2009). Measurement invariance of the composite models (MICOM) approach has been used to confirm measurement invariance (Henseler et al., 2016). MICOM is a three-step approach that includes assessments for:

(1) configural invariance;

(2) compositional invariance; and

(3) equal mean and variance assessment (Henseler et al., 2016).

During data collection and analysis, and an identical set of indicators have been used for the measurement of constructs for both groups. Further, algorithm settings or optimization criteria and data treatment have been kept identical for both groups of employees to ensure the establishment of configural invariance (Henseler et al., 2016).

Permutation method with minimum 1,000 permutations at a 5 per cent significance level has been used to check compositional invariance. This permutation method compared the original score correlations with correlations of empirical distribution after organizing the permutation process. If the original score correlation exceeds the 5 per cent quantile correlations, then the establishment of compositional invariance can be confirmed. Equal mean and variance assessment for the establishment of full measurement invariance for all constructs has been confirmed. Table IV shows the results of measurement invariance for all latent constructs and confirms the presence of full measurement invariance. Table $\mathrm{V}$ presents the difference in a path across two categories of employees. The $p$-values below 0.05 or higher than 0.95 depicts the significant difference in employees of engineering and functional departments. Overall, results found significant differences in both groups for conscientiousness, openness and IB paths. Hence, our hypothesis is partially confirmed.

\section{Discussion}

The purpose of this study was to investigate the relationship of individual PTs on IB and how KSB impacts this relationship. Further, this study also aimed to understand the PT's relationship with IB by comparing employees of engineering and functional departments.

Regarding the individual PT's relationship with IB, conscientiousness, and openness exerted a stronger influence on IB. Hence, study findings are consistent with previous research on the relationship of individual PTs (Woo, 2018). In the case of extraversion, study findings are inconsistent with previous research (Woo, 2018). As openness is linked with creativity, curiosity (Costa and McCrae, 1992) and innovation (Steel et al., 2012), which leads to risk-taking (Choi, 2004), hence, positive relationship of openness with IB is plausible. Those low on creativity and curiosity are less likely to exhibit IB at their jobs in personal or firm benefit.

Conscientiousness is characterized as self-control, planning behaviour and goal orientation (Burtăverde et al., 2017), which leads to innovation and intrapreneurship (Bakx, 2007). Hence, characteristics of high conscientiousness have been the consequence of this study as leading towards IB. A parallel stream of researchers advocates high conscientious people as compliant to existing norms (George and Zhou, 2001), which effects the consequence of intrapreneurship at the individual and firm-level. The hypothesized relationship on the basis of Farrukh et al. (2016) and Sinha and Srivastava (2013) studies have further elaborated in the present study. 


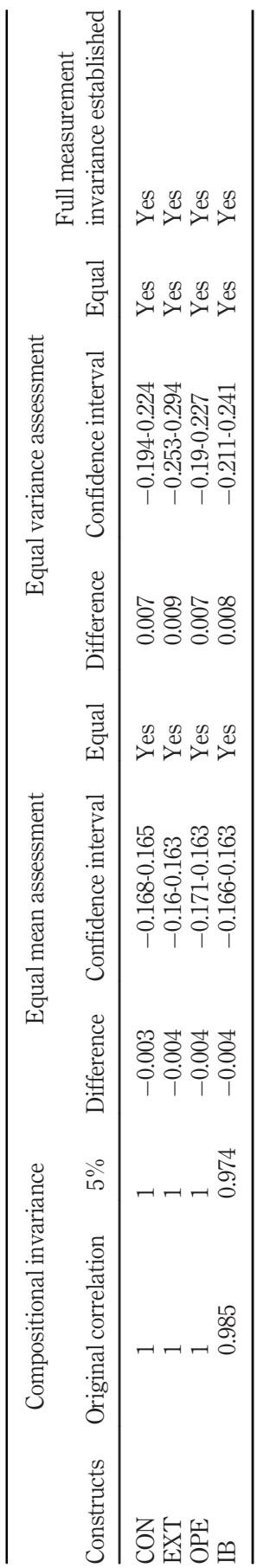

Role of knowledge sharing behaviour

39

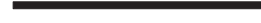

Table IV. Invariance measurement testing using permutation 
APJIE

14,1

40

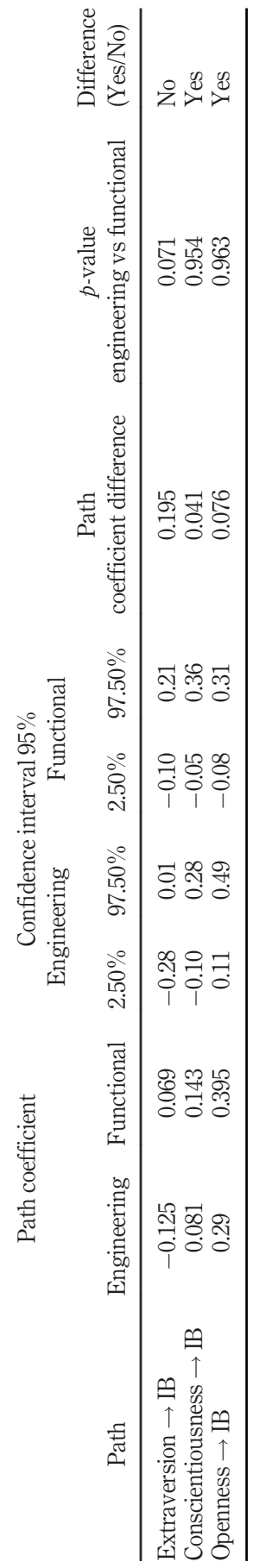

Table V.

Permutation test path coefficient results 
Ambition, energy and dominance associated with extravert people (Costa and McCrae, 1992) stimulate motivation (Burtăverde et al., 2017) and risk-taking (Nicholson et al., 2005), results in intrapreneurial and innovative efforts in traditional jobs (Farrukh et al., 2016; Sinha and Srivastava, 2013). The findings of this study are not consistent with previous research on this antecedent of IB in terms of PT's studies. This is perhaps due to two reasons. Firstly, previous research investigated extraversion relationship with innovation, which is a function of both entrepreneurship and intrapreneurship. Dominance, ambition and energy seem more linked with entrepreneurship and has less likely to affect individuals in traditional jobs. This seems plausible as those who are at traditional jobs are less likely to exhibit dominance, energy and their professional ambitions are somewhat linked with organizations. Secondly, less research on PT's relationships has been done with the perspectives of a developing country. Traditional organizations in developing countries are less likely to promote innovation and intrapreneurship in job settings for the firm or individual benefits as compared to developed countries where innovation and intrapreneurship have gained greater importance.

The study finds that KSB strengthens the PT's (conscientiousness and openness) relationship with IB. Knowledge sharing improves firm performance (Argote and Ingram, 2000) and stimulates creativity (Wang, 2010). As low conscientiousness is linked with low performance at the job (Barrick et al., 2001) and employees with high conscientiousness are better organization citizens who contribute beyond their mandated role (Organ and Ryan, 1995). KSB is part of organization citizenship, which stimulates IB in high conscientious people. As openness has been found to be linked with knowledge sharing (Cabrera et al., 2006), hence, our findings support previous research on openness and KSB as a competitive advantage of firms (Wang, 2010). KSB stimulates creativity and innovation (Wang, 2010) and findings of this study, on strengthening PTs relationship with IB, open avenues for further research on the importance of KSB in organizational perspectives.

This study compared employees of engineering and functional departments in perspectives of PTs as an antecedent of IB. Previous research found engineers quite different in PTs as compared to non-engineers (Williamson et al., 2013). The findings of this study, using MGA, are partially consistent with previous research. Conscientiousness and openness traits relationship with IB is found to be different for employees of engineering and functional departments. This advocates that PTs exhibit differently for the nature of jobs employees are engaged in. Hence, job diversity is an important function of IB while considering PTs. Path coefficients of both groups of employees indicate that the predictive power of employees of functional departments is more as compared to employees of engineering departments. PTs have a strong influence on career choice decisions (Caliendo et al., 2014). This is an interesting finding and consistent with previous research (Williamson et al., 2013). This variation of PTs on IB in both groups of employees is there probably due to the nature of the job, previous education and workplace environment.

\section{Theoretical and practical implications}

This study has contributed to intrapreneurship literature by providing insights on PTs impacting IB by incorporating KSB. PTs of individuals have less scope of improvement as regards to organizational perspectives. Organizations can do little in the form of training sessions and improving organization citizenship to effect on PTs. As regards the consequence of IB within organizations, knowledge sharing culture is a way out. KSB of employees results in innovation and creativity, which results in the firm's competitive advantage through intrapreneurship. KSB of employees is comparatively easy to improve in organizations through management focus. The nature and role of employees in the

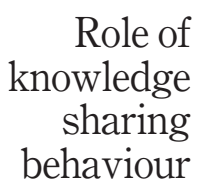

41 
APJIE 14,1

organization have an effect on individual perceptions and PTs. In departments where employees are doing technical or engineering related jobs, overall communication, socialization and environment are different from departments where functional jobs are performed. To raise engineers to be an entrepreneur or intrapreneur, pedagogical evolution in the engineering curriculum is deemed necessary, which has now been realized by engineering institutions.

\section{Limitations and future research directions}

Few limitations of the present study open avenues for future research on PTs, KSB and IB. Firstly, though comparison with respect to PTs of employees has been done, yet generalization of this study on developing countries is difficult due to the diverse nature of jobs and effects due to individual organization culture. In the public sector, diversity due to organizational culture is envisaged to effect less as compared to private sector organizations where organization culture and norms vary considerably. Secondly, the moderated role of only KSB has been considered, whereas many more mediators and moderators are expected to exert influence on PTs and IB. Hence, a combination of more influencers of IB can better explain the phenomenon in future research. Thirdly, this study advocates the importance of $\mathrm{KSB}$ of employees in organizations but how this knowledge sharing will come into play in engineering or functional departments, have not been elaborated. Future research on the effects of knowledge sharing to promote intrapreneurship with the perspective of the different organizational roles of employees will bring further insights. Fourthly, only a few PTs have been incorporated in the model of this study. Future researchers to incorporate more PTs to gain deeper insights on employee diversity due to the nature of the job. The findings make an explicit comparison to explain the difference in PTs of employees in different departments. This open avenue for future research on intrapreneurship as the organizational role has effects on employees to engage in intrapreneurship.

\section{Conclusions}

As regards developing country's perspectives at the policy level, intrapreneurship is easy to manage, facilitate, legislate and sustain as compared to entrepreneurship. The importance of entrepreneurial start-ups cannot be ignored, intrapreneurial engagements are more relevant and seem effective for developing countries. Human beings have habits, nature, PTs and ways of working, which matures with experience and age. Organizations have to absorb all human-related personality effects to sustain competitive advantage in a diverse environment. The deficiencies in employee training, pedagogics and within organization culture to promote intrapreneurship, can be enhanced through effective engagement of knowledge sharing.

Intrapreneurship and knowledge sharing are increasingly recognized as an important aptitude of employees in a diverse global business environment. This study has open avenues for research on PTs relationship with intrapreneurship in various other contexts. Moreover, the findings of this study can be useful for human resource departments in corporations in selecting engineers and other professionals for employments according to PTs suitable for specific employment.

This research study proposed and tested an integrated model of determinants of intrapreneurship. Intrapreneurship as an auxiliary of entrepreneurship can altogether be defined as a function of PTs. The relevance of intrapreneurship for engineering professionals is very important. Today's high-tech organizations solely rely on aggressive innovative ideas to retain a competitive advantage in the market. This demands highly innovative professionals in organizations who can create ventures within the organization for the global community. These highly innovative professionals in organizations cannot be created from pedagogical evolutions, rather professionals of specific PTs can be carefully selected for specified roles. 


\section{References}

A $\breve{c c a}$, V., Topal, Y. and Kaya, H. (2012), "Linking intrapreneurship activities to multidimensional firm performance in Turkish manufacturing firms: an empirical study", International Entrepreneurship and Management Journal, Vol. 8 No. 1, pp. 15-33.

Alam, M.Z., Kousar, S. and Rehman, C.A. (2019), "Role of entrepreneurial motivation on entrepreneurial intentions and behaviour: theory of planned behaviour extension on engineering students in Pakistan”, Journal of Global Entrepreneurship Research, Vol. 9 No. 1, pp. 1-20.

Åmo, B.W. and Kolvereid, L. (2005), "Organizational strategy, individual personality and innovation behavior", Journal of Enterprising Culture, Vol. 13 No. 1, pp. 7-19.

Antoncic, B. and Hisrich, R.D. (2003), "Clarifying the intrapreneurship concept", Journal of Small Business and Enterprise Development, Vol. 10 No. 1, pp. 7-24.

Argote, L. and Ingram, P. (2000), "Knowledge transfer: a basis for competitive advantage in firms", Organizational Behavior and Human Decision Processes, Vol. 82 No. 1, pp. 150-169.

Augusto Felício, J., Rodrigues, R. and Caldeirinha, V.R. (2012), "The effect of intrapreneurship on corporate performance", Management Decision, Vol. 50 No. 10, pp. 1717-1738.

Bakx, N. (2007), "Which personality traits do innovative people possess", "Masters full thesis", University of Amsterdam.

Barrick, M.R. and Mount, M.K. (1991), “The big five personality dimensions and job performance: a meta-analysis", Personnel Psychology, Vol. 44 No. 1, pp. 1-26.

Barrick, M.R., Mount, M.K. and Judge, T.A. (2001), "Personality and performance at the beginning of the new millennium: what do we know and where do we go next?", International Journal of Selection and Assessment, Vol. 9 Nos 1/2, pp. 9-30.

Burgers, J.H. and Covin, J.G. (2016), "The contingent effects of differentiation and integration on corporate entrepreneurship", Strategic Management Journal, Vol. 37 No. 3, pp. 521-540.

Burtăverde, V., Chraif, M., Aniţ ei, M. and Dumitru, D. (2017), “The HEXACO model of personality and risky driving behavior", Psychological Reports, Vol. 120 No. 2, pp. 255-270.

Cabrera, A., Collins, W.C. and Salgado, J.F. (2006), "Determinants of individual engagement in knowledge sharing", The International Journal of Human Resource Management, Vol. 17 No. 2 , pp. 245-264.

Caliendo, M., Fossen, F. and Kritikos, A.S. (2014), "Personality characteristics and the decisions to become and stay self-employed", Small Business Economics, Vol. 42 No. 4, pp. 787-814.

Chin, W.W. and Newsted, P.R. (1999), "Structural equation modeling analysis with small samples using partial least squares”, Statistical Strategies for Small Sample Research, Vol. 1 No. 1, pp. 307-341.

Choi, J.N. (2004), "Individual and contextual predictors of creative performance: the mediating role of psychological processes", Creativity Research Journal, Vol. 16 No. 2-3, pp. 187-199.

Costa, P.T. Jr and McCrae, R.R. (1992), "Revised NEO personality inventory (NEO-PI-R) and NEO fivefactor (NEO-FFI) inventory professional manual", PAR, Odessa, $F l$.

Covin, J.G. and Wales, W.J. (2012), “The measurement of entrepreneurial orientation”, Entrepreneurship Theory and Practice, Vol. 36 No. 4, pp. 677-702.

Davenport, T.H. and Prusak, L. (1998), Working Knowledge: How Organizations Manage What They Know, Harvard Business Press, Brighton.

Digman, J.M. (1990), "Personality structure: emergence of the five-factor model", Annual Review of Psychology, Vol. 41 No. 1, pp. 417-440.

Dushnitsky, G. and Lavie, D. (2010), "How alliance formation shapes corporate venture capital investment in the software industry: a resource-based perspective", Strategic Entrepreneurship Journal, Vol. 4 No. 1, pp. $22-48$.

Espinosa, MdMB. and Suanes, A.M. (2011), "Corporate entrepreneurship through joint venture", International Entrepreneurship and Management Journal, Vol. 7 No. 3, pp. 413-430.

\section{Role of \\ knowledge sharing behaviour}


APJIE 14,1

Farrukh, M., Ying, C.W. and Mansori, S. (2016), "Intrapreneurial behavior: an empirical investigation of personality traits", Management and Marketing, Vol. 11 No. 4, pp. 597-609.

Farrukh, M., Chong, W.Y., Mansori, S. and Ravan Ramzani, S. (2017), "Intrapreneurial behaviour: the role of organizational commitment", World Journal of Entrepreneurship, Management and Sustainable Development, Vol. 13 No. 3, pp. 243-256.

Fietze, S. and Boyd, B. (2017), "Entrepreneurial intention of Danish students: a correspondence analysis", International Journal of Entrepreneurial Behavior and Research, Vol. 23 No. 4, pp. 656-672.

Fornell, C. and Larcker, D.F. (1981), Structural Equation Models with Unobservable Variables and Measurement Error: Algebra and Statistics, SAGE Publications, Los Angeles, CA.

George, J.M. and Zhou, J. (2001), "When openness to experience and conscientiousness are related to creative behavior: an interactional approach", Journal of Applied Psychology, Vol. 86 No. 3, pp. 513-524.

Gillani, S.M.F., Iqbal, S., Akram, S. and Rasheed, M. (2018), "Specific antecedents of employees' knowledge sharing behavior", VINE Journal of Information and Knowledge Management Systems, Vol. 48 No. 2, pp. 178-198.

Goldberg, L.R. (1992), "The development of markers for the Big-Five factor structure", Psychological Assessment, Vol. 4 No. 1, pp. 26-42.

Hair, J.F., Ringle, C.M. and Sarstedt, M. (2011), "PLS-SEM: indeed a silver bullet”, Journal of Marketing Theory and Practice, Vol. 19 No. 2, pp. 139-152.

Hair, J.F., Jr, Hult, G.T.M., Ringle, C. and Sarstedt, M. (2016), A Primer on Partial Least Squares Structural Equation Modeling (PLS-SEM), Sage publications, Thousand Oaks, CA.

Hair, J.F., Ringle, C.M., Gudergan, S.P., Fischer, A., Nitzl, C. and Menictas, C. (2019), "Partial least squares structural equation modeling-based discrete choice modeling: an illustration in modeling retailer choice”, Business Research, Vol. 12 No. 1, pp. 115-142.

Halme, M., Lindeman, S. and Linna, P. (2012), "Innovation for inclusive business: intrapreneurial bricolage in multinational corporations", Journal of Management Studies, Vol. 49 No. 4, pp. 743-784.

Henseler, J., Ringle, C.M. and Sarstedt, M. (2016), “Testing measurement invariance of composites using partial least squares", International Marketing Review, Vol. 33 No. 3, pp. 405-431.

Henseler, J., Ringle, C.M. and Sinkovics, R.R. (2009), "The use of partial least squares path modeling in international marketing", New Challenges to International Marketing, Emerald Group Publishing, Bingley, pp. 277-319.

Hurtz, G.M. and Donovan, J.J. (2000), "Personality and job performance: the big five revisited”, Journal of Applied Psychology, Vol. 85 No. 6, pp. 869-879.

Imran, M.K., Ilyas, M., Aslam, U. and Fatima, T. (2018), "Knowledge processes and firm performance: the mediating effect of employee creativity", Journal of Organizational Change Management, Vol. 31 No. 3, pp. 512-531.

Ireland, R.D., Covin, J.G. and Kuratko, D.F. (2009), "Conceptualizing corporate entrepreneurship strategy", Entrepreneurship Theory and Practice, Vol. 33 No. 1, pp. 19-46.

John, O.P. and Srivastava, S. (1999), "The big five trait taxonomy: history, measurement, and theoretical perspectives", Handbook of Personality: Theory and Research, Vol. 2, pp. 102-138.

John, O.P., Naumann, L.P. and Soto, C.J. (2008), "Paradigm shift to the integrative big five trait taxonomy", Handbook of Personality: Theory and Research, Vol. 3 No. 2, pp. 114-158.

Kim, S. and Lee, H. (2004), "Organizational factors affecting knowledge sharing capabilities in egovernment: an empirical study", IFIP International Working Conference on Knowledge Management in Electronic Government, Springer, pp. 281-293.

Kirkley, W.W. (2017), "Cultivating entrepreneurial behaviour: entrepreneurship education in secondary schools", Asia Pacific Journal of Innovation and Entrepreneurship, Vol. 11 No. 1, pp. 17-37.

Kuratko, D.F. (2017), “Corporate entrepreneurship 2.0: research development and future directions", Foundations and Trends ${ }^{\circledR}$ in Entrepreneurship, Vol. 13 No. 6, pp. 441-490. 
Lim, P. and Melissa Ng Abdullah, L. (2012), "Relationship between big-five personality domains and students' academic achievement”, Pertanika Journal of Social Sciences and Humanities, Vol. 20 No. 4, pp. 973-988.

Matzler, K., Renzl, B., Müller, J., Herting, S. and Mooradian, T.A. (2008), "Personality traits and knowledge sharing", Journal of Economic Psychology, Vol. 29 No. 3, pp. 301-313.

Menzel, H.C., Aaltio, I. and Ulijn, J.M. (2007), "On the way to creativity: engineers as intrapreneurs in organizations", Technovation, Vol. 27 No. 12, pp. 732-743.

Meyer, R.D., Dalal, R.S., José, I.J., Hermida, R., Chen, T.R., Vega, R.P., Brooks, C.K. and Khare, V.P. (2014), "Measuring job-related situational strength and assessing its interactive effects with personality on voluntary work behavior", Journal of Management, Vol. 40 No. 4, pp. 1010-1041.

Mittal, S. and Dhar, R.L. (2015), "Transformational leadership and employee creativity: mediating role of creative self-efficacy and moderating role of knowledge sharing", Management Decision, Vol. 53 No. 5, pp. 894-910.

Nicholson, N., Soane, E., Fenton-O'Creevy, M. and Willman, P. (2005), "Personality and domain-specific risk taking", Journal of Risk Research, Vol. 8 No. 2, pp. 157-176.

Obschonka, M. and Stuetzer, M. (2017), "Integrating psychological approaches to entrepreneurship: the entrepreneurial personality system (EPS)”, Small Business Economics, Vol. 49 No. 1, pp. 203-231.

Organ, D.W. and Ryan, K. (1995), "A Meta-analytic review of attitudinal and dispositional predictors of organizational citizenship behavior”, Personnel Psychology, Vol. 48 No. 4, pp. 775-802.

Park, C. (2017), "A study on effect of entrepreneurship on entrepreneurial intention: focusing on ICT majors", Asia Pacific Journal of Innovation and Entrepreneurship, Vol. 11 No. 2, pp. 159-170.

Parker, S.K. and Collins, C.G. (2010), "Taking stock: integrating and differentiating multiple proactive behaviors", Journal of Management, Vol. 36 No. 3, pp. 633-662.

Scott, S.G. and Bruce, R.A. (1994), "Determinants of innovative behavior: a path model of individual innovation in the workplace", Academy of Management Journal, Vol. 37 No. 3, pp. 580-607.

Shin, S.S. and Lee, S. (2016), "An examination of firms' strategic orientations, innovativeness and performance with large Korean companies", Asia Pacific Journal of Innovation and Entrepreneurship, Vol. 10 No. 1, pp. 183-202.

Sieger, P., Zellweger, T. and Aquino, K. (2013), "Turning agents into psychological principals: aligning interests of non-owners through psychological ownership", Journal of Management Studies, Vol. 50 No. 3, pp. 361-388.

Sinha, N. and Srivastava, K.B. (2013), "Association of personality, work values and socio-cultural factors with intrapreneurial orientation", The Journal of Entrepreneurship, Vol. 22 No. 1, pp. 97-113.

Srivastava, S., Sultan, A. and Chashti, N. (2017), "Influence of innovation competence on firm level competitiveness: an exploratory study", Asia Pacific Journal of Innovation and Entrepreneurship, Vol. 11 No. 1, pp. 63-75.

Steel, G.D., Rinne, T. and Fairweather, J. (2012), "Personality, nations, and innovation: relationships between personality traits and national innovation scores", Cross-Cultural Research, Vol. 46 No. 1, pp. 3-30.

Tseng, C. and Tseng, C.-C. (2019), "Corporate entrepreneurship as a strategic approach for internal innovation performance", Asia Pacific Journal of Innovation and Entrepreneurship, Vol. 13 No. 1, pp. 108-120.

Valsania, S.E., Moriano, J.A. and Molero, F. (2016), “Authentic leadership and intrapreneurial behavior: cross-level analysis of the mediator effect of organizational identification and empowerment", International Entrepreneurship and Management Journal, Vol. 12 No. 1, pp. 131-152.

Wang, K.Y., Hermens, A., Huang, K.P. and Chelliah, J. (2015), "Entrepreneurial orientation and organizational learning on SMEs' innovation”, International Journal of Organizational Innovation, Vol. 7 No. 7, pp. 71-81. 
APJIE 14,1

Wang, M. (2010), "Influence of knowledge sharing and project complexity on group creativity: taking the development of information system for example", Journal of e-Business, Vol. 12 No. 1 , pp. 73-102.

Williamson, J.M., Lounsbury, J.W. and Han, L.D. (2013), "Key personality traits of engineers for innovation and technology development", Journal of Engineering and Technology Management, Vol. 30 No. 2, pp. 157-168.

Woo, H.R. (2018), "Personality traits and intrapreneurship: the mediating effect of career adaptability", Career Development International, Vol. 23 No. 2, pp. 145-162.

Zahra, S.A. (2015), "Corporate entrepreneurship as knowledge creation and conversion: the role of entrepreneurial hubs", Small Business Economics, Vol. 44 No. 4, pp. 727-735.

Zhao, H., Seibert, S.E. and Hills, G.E. (2005), "The mediating role of self-efficacy in the development of entrepreneurial intentions", Journal of Applied Psychology, Vol. 90 No. 6, pp. 1265-1272.

Zhao, H., Seibert, S.E. and Lumpkin, G.T. (2010), "The relationship of personality to entrepreneurial intentions and performance: a Meta-analytic review", Journal of Management, Vol. 36 No. 2, pp. 381-404.

\section{Corresponding author}

Muhammad Zubair Alam can be contacted at:alam_zubair@hotmail.com

For instructions on how to order reprints of this article, please visit our website: 